\title{
ANOTHER NEW SPECIES OF RAFFLESIA (RAFFLESIACEAE) FROM LUZON, PHILIPPINES: R. LEONARDI
}

\author{
JULIE F. BARCELONA ${ }^{1}$, PIETER B. PELSER ${ }^{2}$, \\ ERIC M. CABUTAJE ${ }^{3} \&$ NESTOR A. BARTOLOME 4
}

\begin{abstract}
SUMMARY
Anew species of Philippine Rafflesia is described. Rafflesia leonardi is the eighth species of Rafflesia described from the Philippines and the fourth species from Luzon Island. It most closely resembles $R$. lobata and $R$. manillana in perigone colour and wart ornamentations and in the wide aperture relative to diaphragm diameter. It is, however, different from both of these and other Philippine Rafflesia species in its flower size and disk that lacks or has rudimentary processes.
\end{abstract}

Key words: Rafflesiaceae, Rafflesia, Philippines, Cagayan, conservation, taxonomy.

\section{INTRODUCTION}

The discovery of Rafflesia speciosa (Barcelona \& Fernando 2002) from the island of Panay in the Philippines marked the start of a renewed interest in the study of Philippine Rafflesia and resulted in the description of four additional species new to science: $R$. mira (Fernando \& Ong 2005) (syn. R. magnifica Madulid et al. 2006) from Mt Candalaga, Compostela Valley in Mindanao, R. baletei (Barcelona et al. 2006) from Mt Isarog and Mt Asog in Camarines Sur in Luzon, R. lobata (Galang \& Madulid 2006) from Antique and Iloilo in Panay, and R. banahawensis (Barcelona et al. 2007; Madulid et al. 2007) from Mt Banahaw, Quezon in Luzon. Together with the previously described R. manillana (Teschemacher 1844) and R. schadenbergiana (Hieronymous 1885), this brought the total number of Philippine Rafflesia species to seven. The end of this period of growing knowledge on the biodiversity of Rafflesia in the Philippines is, however, not in sight as evidenced by the discovery of yet another new species of Rafflesia during fieldwork by the Cagayan Valley Partners in People Development (CAVAPPED) and the local community in north-eastern Luzon in 2005. This is the eighth Rafflesia species to be described in the Philippines and the fourth known from Luzon.

1) Philippine National Herbarium (PNH), Botany Division, National Museum of the Philippines, P. Burgos St., Manila, P.O. Box 2659, Philippines; e-mail: barceljf@hotmail.com.

2) Miami University, Botany Department, 316 Pearson Hall, Oxford, Ohio, USA; e-mail: pelserpb@muohio.edu.

3) Cagayan Valley Partners in People Development (CAVAPPED), 32 Lecaros St., Ugac Sur, Tuguegarao City 3500, Philippines.

4) Conservation International-Philippines, 6 Maalalahanin St., Teacher's Village, Diliman, Quezon City 1101, Philippines. 


\section{Rafflesia leonardii Barcelona \& Pelser, spec. nov. — Fig. 1; Plate 1}

Habitu Rafflesiae manillanae et $R$. lobatae similis in hospitis radicibus stirpibusque crescens, perigonii colore, verrucarum morphologia, diaphragmae ore lato, ab ambabus flore maiore, perigonii tubo sine maculis albis, disco fere plano sine vel paucis processis brevibus quodam modo illo $R$. rochussenii simili differt. - Typus: Barcelona et al. 3355 (holo, male open flower, PNH; iso, male bud, US; male semi-open flower, L), Philippines, Luzon, Cagayan Province, Gattaran Municipality, Barangay Bolos Point, Sitio Kanapawan.

Mature buds to $16 \mathrm{~cm}$ diameter. Basal cupule c. $3.5 \mathrm{~cm}$ high, c. $7.5 \mathrm{~cm}$ wide. Bracts (or bud scales) in three imbricate whorls, outermost smallest, c. 3 by $4 \mathrm{~cm}$, largest innermost ones to 12 by $8 \mathrm{~cm}$. Flowers (25.5-)28-34 cm diam. when fully expanded, 13.8-18 $\mathrm{cm}$ high, male and female flowers similar in size and shape. Perigone tube 9-11 cm long. Perigone lobes 5 (or 6), orbicular to broadly orbicular, $7.5-13$ by $11-13.5 \mathrm{~cm}$, base slightly auriculate, reddish orange, becoming darker with age, margins entire to irregularly sinuate, tan to pale yellow, warts prominent on the upper surface, mostly elliptic or roundish, larger warts interspersed with tiny ones, powdery white when fresh, becoming concolorous with background with age. Diaphragm 14-18(-22) cm diam., $2.5-3 \mathrm{~cm}$ wide from aperture rim to base of perigone lobe, $3-10 \mathrm{~mm}$ thick at base, becoming thinner towards the aperture, background concolorous with perigone, outer surface with shallow indentations from the perigone warts when the flower was in bud stage, marked with roundish tan coloured warts, some of which are elevated on mamilla, surrounded by tiny tan coloured speckles, windows absent; aperture 10.5-12.5(-19) cm diam., rim maroon in colour. Disk 7-8 cm diam., c. $1.2-1.3 \mathrm{~cm}$ thick midway between the margin and the point where the disk joins the column, nearly flat to slightly dome-shaped with a slightly raised margin, tan centrally, purplish maroon towards the periphery, devoid of or with few, rudimentary processes, margin irregularly and shallowly incised or crenulate, corona smooth, sparsely and minutely pubescent, cream-colored in bud; processes when present, up to 10, often tuberculate, sometimes pointed, up to $5 \mathrm{~mm}$ long, very seldom longer, dark maroon; column 3-5 $\mathrm{cm}$ from the base of cupule to the upper surface of disk; neck of column c. $3 \mathrm{~mm}$ long, c. $4.5 \mathrm{~mm}$ wide; annulus c. $1 \mathrm{~cm}$ wide, c. $9 \mathrm{~cm}$ diam., smooth, glabrous, whitish in the inner part, darker in the outer part. Ramenta dimorphic, to $2 \mathrm{~mm}$ long, those toward the base of perigone tube filiform, dense, those inside diaphragm stout, branched or cleaved apically, tips darker. Male flower without vestigial ovary; anthers 20 (or 21), semi-globular, c. $3 \mathrm{~mm}$ diam., deeply immersed in anther sulci that are $8-9 \mathrm{~mm}$ long and c. $5 \mathrm{~mm}$ wide. Female flower as big as the male, without vestigial anthers, ovary c. $1.2 \mathrm{~cm}$ tall, $6 \mathrm{~cm}$ wide, lunate.

Etymology - This beautiful Rafflesia species is named after Mr. Leonardo L. Co. With his enormous knowledge of the Philippine flora, Leonard (to colleagues and friends) has been a mentor to the first author and many other students of Philippine botany. He spent most of his prolific botanical career in Luzon's Sierra Madre Mountain Range where $R$. leonardi is found.

Distribution - Philippines: Cagayan Province, Luzon, Gattaran and Lal-lo Municipalities.

Habitat \& Ecology - Logged-over lowland dipterocarp forests at 270-300 m asl, thus far the lowest elevation for Rafflesia populations in the Philippines. Rafflesia 


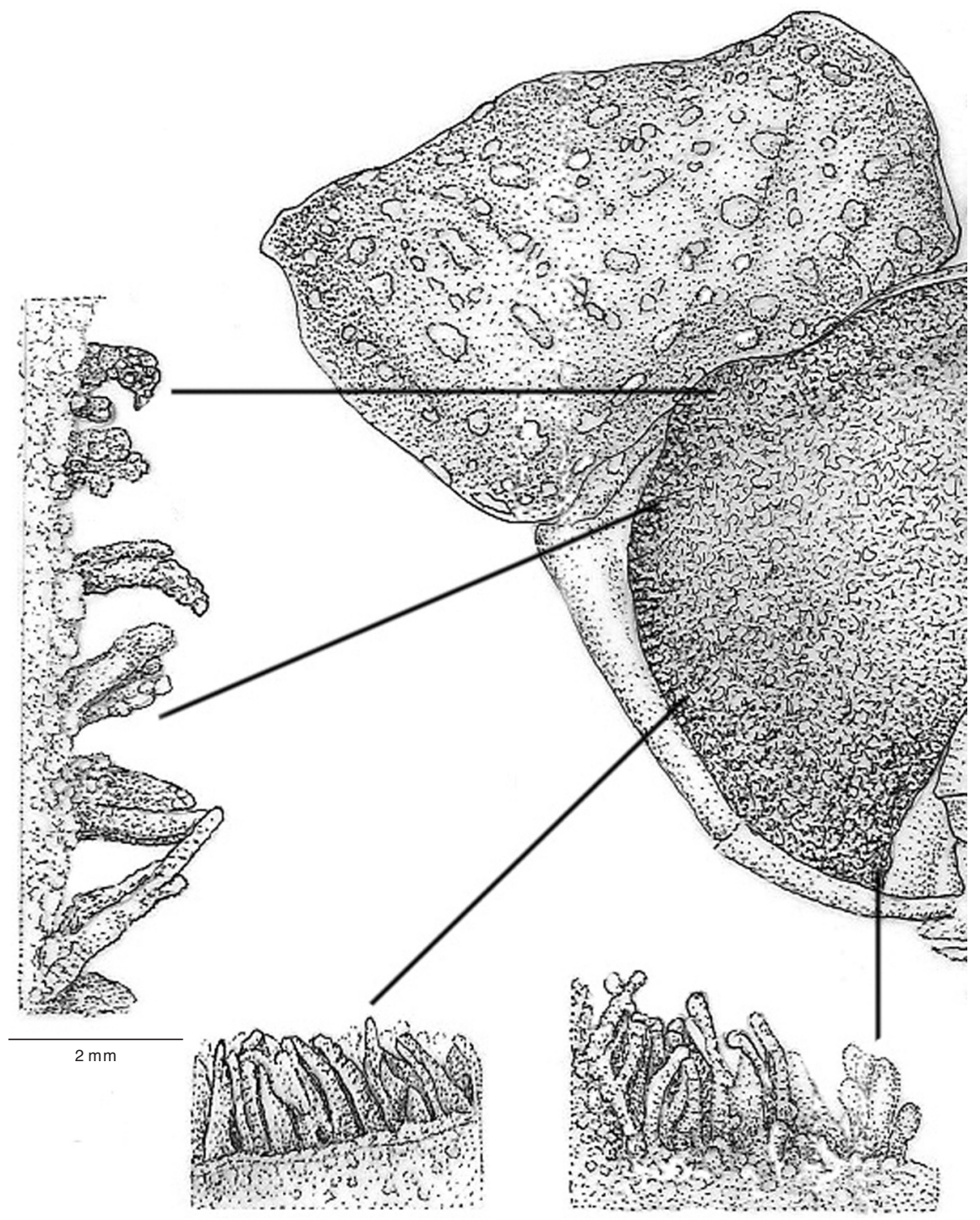

Fig. 1. Rafflesia leonardi Barcelona \& Pelser. Magnified ramenta from different portions along the inside of the perigone tube and diaphragm (Barcelona et al. 3354).

leonardi usually grows along river and stream banks on thin soil and rocky substrate and among trees that have exposed roots and form buttresses. A total of six populations were found in the area. Tetrastigma cf. loheri (Barcelona et al. 3356, PNH, US) was identified as the host plant. On one host plant a total of ten buds and four developing fruits were observed, although usually fewer flowers per host plant seem to be produced. Rafflesia leonardi not only forms flowers on the exposed roots of its host, but also blooms along the aerial portions of the host liana (Plate 1a), some buds reaching 

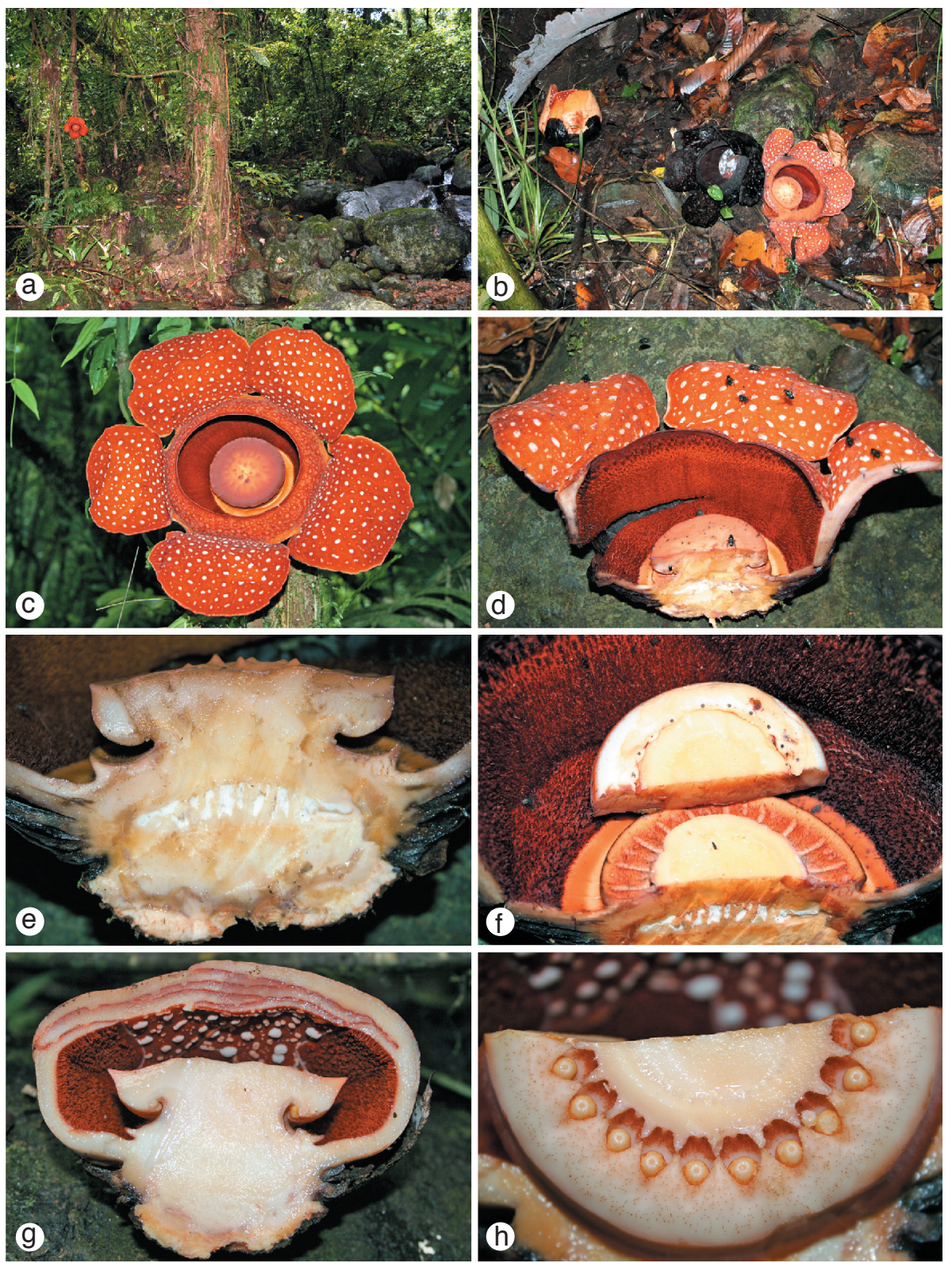

Plate 1. Rafflesia leonardi Barcelona \& Pelser. a. Aerial habit of an open flower on trunk of the host plant (Tetrastigma cf. loheri) growing along a streambank; b. flowers in different stages of development emerging from the roots of the host plant; $\mathrm{c}$. male flower showing perigone lobes with auriculate bases and sinuate margins; $d-f$. longitudinal section of a female flower, showing: e. ovary and f. stigmatic surface (disk cut off); g. longitudinal section of a male bud; h. minutely pubescent undersurface of the disk corona showing anthers deeply immersed in sulci (a, c: Barcelona et al. 3355 (holotype); d-f: Barcelona et al. 3354; b, g, h: Barcelona et al. 3355 (isotypes)). - Photos: J.F. Barcelona. 
a height of c. $10 \mathrm{~m}$ above the ground. In the Philippines, three other species, $R$. lobata, $R$. manillana, and $R$. speciosa exhibit this aerial habit. Rafflesia leonardi is sympatric with $R$. manillana, known from Luzon, Samar, and Leyte. At one site for instance, a population of $R$. leonardi is located less than $10 \mathrm{~m}$ from a population of $R$. manillana. Populations of both Rafflesia species in the Cagayan area rely on Tetrastigma cf. loheri as a host. Other species of Tetrastigma appeared to be absent from the areas where Rafflesia populations have been found. Tetrastigma loheri was also reported as the host of $R$. mira of Compostela Valley in Mindanao. Common canopy trees in the area are Dillenia philippinensis, Dipterocarpus validus, Pterospermum niveum, Shorea contorta, S. palosapis, and Terminalia foetidissima. The understory layer is composed of Astronia spp., Ficus spp., Leea congesta, Leptonychia banahaensis, Saurauia klemmei, and Syzygium curranii. Rattans and Freycinetia spp. also abound. The herbaceous layer consists of the angiosperm genera Begonia, Cyrtandra, and Donax cannaeformis, and the fern genera Asplenium, Microsorum, Pleocnemia, and Tectaria.

Morphological affinities - Rafflesia leonardi is similar in habit to R. lobata, $R$. manillana, and $R$. speciosa in that it blooms from both the roots and aerial portions of the host. It is further similar to $R$. lobata and $R$. manillana in perigone colour (different hues of reddish orange) and the shape and density of the perigone warts, but mostly in the relatively wide diaphragm opening, which is much narrower in all other Rafflesia species. The diaphragm is reminiscent of R. speciosa. The colour and morphology of the ramenta are very similar to those of $R$. banahawensis, which are maroon, variably branched, and stouter and more densely clustered in the diaphragm than in the perigone tube. The white spots or windows inside the perigone tube and diaphragm, typical in both $R$. lobata and R. manillana, are absent in R. leonardi. Rafflesia leonardi differs from all other Philippine Rafflesia species in the overall size of the open flower which is intermediate between the small-sized $R$. baletei, $R$. banahawensis, $R$. lobata, and $R$. manillana, and the medium-sized $R$. mira and $R$. speciosa. It is also different in characters of the disk, which is nearly flat to slightly dome-shaped and devoid of or with few processes, somewhat resembling the disk of $R$. rochussenii from Indonesia.

Conservation - The presence of two species of Rafflesia in the Cagayan area, the only case of sympatry in Rafflesia ever recorded in the Philippines, supports previous studies emphasizing the uniquely high yet poorly understood biological diversity in this part of the Sierra Madre mountain range (Danielsen et al. 1994; Co et al. 2006). This discovery strengthens proposals for the establishment of a Protected Area system currently being initiated by CAVAPPED and partner Peoples' Organizations (POs), Non-governmental Organizations (NGOs) and Local Government Units (LGUs). The dipterocarp forests in this portion of northern Luzon, although logged-over, are still in good condition. Small-scale rattan gathering by the local community was observed. Timber poaching for premium hardwood, such as narra (Pterocarpus indicus), was also evident. Slash-and-burn (kaingin) seems to be the most significant threat to Rafflesia populations in Cagayan. Although currently there are only a few small kaingin patches in adjacent areas, we predict that its impact will increase as these patches become larger and more numerous with the growing population in the area.

Specimens studied:

PHILIPPINES. Luzon, Cagayan Valley Prov., Gattaran and Lal-lo Municipalities, Barangay Bolos Point, Sitio Kanapawan: Barcelona et al. 3355 (holo PNH; iso L, PUH, US); Barcelona et al. 3354 (PNH). 


\section{ACKNOWLEDGEMENTS}

We dedicate the discovery of the Rafflesia leonardi to the Agta community of the Sierra Madre Mountain Range of Luzon, especially Sumper Aresta who first discovered the population in Barangay Bolos Point, Gattaran, Cagayan Valley in 2005. The Cagayan Valley Partners in People Development (CAVAPPED) through its President/CEO Perla A. Visorro, initiated the field verification and documentation with financial support from the Foundation for Philippine Environment (FPE). We thank the National Museum of the Philippines (NMP), Conservation International-Philippines (CIPhilippines), the Department of Environment and Natural Resources (DENR), Provincial Environment and Natural Resources Office (PENRO) of the DENR, and the Local Government Unit, Cagayan Valley (PENREO) for supporting our research endeavour, Nemesio M. Diego Jr. for scientific illustrations and Jan-Frits Veldkamp for providing the Latin diagnosis. Our sincere gratitude goes out to those who provided company during the week-long fieldwork at Bolos Point, namely, Sherwin Buguina (CAVAPPED), Franklyn Dalin and Juan Ariola (CI-Philippines), Jovencio Payba (PENRODENR), David Duropan (PENREO-LGU, Cagayan Valley), and Rolando Echanique, Chairman of the Federation of Bolos Point People's Organization. We also thank our guides, Nemesio Macutay, Elmer Casani, Sumper and Mario Aresta, Tidtid and Pilo Bayanay, Poner and Lyn Salazar, Erming and Lilibeth Pattung.

\section{REFERENCES}

Barcelona, J.F., M.O. Cajano \& A.S. Hadsall. 2006. Rafflesia baletei, another new Rafflesia (Rafflesiaceae) from the Philippines. Kew Bull. 61: 231-237.

Barcelona, J.F. \& E. S. Fernando. 2002. A new species of Rafflesia (Rafflesiaceae) from Panay Island, Philippines. Kew Bull. 57: 647-651.

Barcelona, J.F., P.B. Pelser \& M.O. Cajano. 2007. Rafflesia banahaw (Rafflesiaceae), a new species from Luzon, Philippines. Blumea 52: 345-350.

Co, L.L., D.A. Lagunzad, K.A.C. Pasion, H.T. Consunji, N.A. Bartolome, S.L. Yap, J.E. Molina, M.D.C. Tongco, U.F. Ferreras, J.V. LaFrankie, S.J. Davies \& P.S. Ashton. 2006. Forest trees of Palanan, Philippines: A study in population ecology. Center for Tropical Forest Science. Center for Integrative and Development Studies, University of the Philippines-Diliman, Quezon City, Philippines.

Danielsen, F., D. S. Balete, T.D. Christensen, M. Heegaard, O.F. Jacobsen, A. Jensen, T. Lund \& M.K. Poulsen. 1994. Conservation of biological diversity in the Sierra Madre mountains of Isabela and southern Cagayan provinces, the Philippines. Department of Environment and Natural Resources, Birdlife International and Danish Ornithological Society, Manila and Copenhagen.

Fernando, E. S. \& P.S. Ong. 2005. The genus Rafflesia R.Br. (Rafflesiaceae) in the Philippines. Asia Life Sci. 14: 263-270.

Galang, R. \& D.A. Madulid. 2006. A second new species of Rafflesia (Rafflesiaceae) from Panay Island, Philippines. Folia Malaysiana. 7: 1-8.

Hieronymous, G. 1885. Ueber eine neue, von Dr. A. Schadenberg und O. Koch auf Süd-Mindanao entdeckte Art der Gattung Rafflesia. Gartenflora 34: 3-7, t. 1177.

Madulid, D.A., D. Tandang \& E.M.G. Agoo. 2006 ('2005'). Rafflesia magnifica (Rafflesiaceae), a new species from Mindanao, Philippines. Acta Manilana 53: 1-6.

Madulid, D. A., C. Villariba-Tolentino \& E.M.G. Agoo. 2007 ('2006'). Rafflesia banahawensis (Rafflesiaceae), a new species from Luzon, Philippines. Philipp. Scientist 43: 43-51.

Teschemacher, J.E. 1844. On a new species of Rafflesia, from Manilla. Boston J. Nat. Hist. 4: 63-66, t. 6. 